\title{
AN EMPIRICAL ANALYSIS OF THE RELATIONSHIP BETWEEN BANK CREDIT AND ECONOMIC GROWTH
}

\author{
Uma Análise Empírica da Relação entre Crédito Bancário e Crescimento \\ Econômico
}

\author{
Marcos Roberto Vasconcelos \\ Universidade Estadual de Maringá, Maringá-PR, Brasil \\ mrvasconcelos@uem.br \\ Vítor Gomes Reginato \\ Universidade Estadual de Maringá, Maringá-PR, Brasil \\ vitoreginato@hotmail.com \\ Marina Silva da Cunha \\ Universidade Estadual de Maringá, Maringá-PR, Brasil \\ mscunha@uem.br
}

\begin{abstract}
Objective: This paper tests the hypothesis that bank credit is necessary for economic growth, depending on the country's level of economic and financial development. It also seeks to verify whether the relationship between financial development and economic growth is monotonic. Methods: For this, Granger's causality methodology is used for panel data, with data from 106 countries for the period between 1970 and 2016. Results: It is observed that there was an expansion of world credit above the economic growth observed over the studied period. The main empirical findings indicate that, in general, credit causes economic growth and vice versa, in addition to verifying the non-monotonicity of the relationship between financial development and economic growth, so that, for low credit / GDP indices, the causality of the credit to GDP is not verified. Conclusions: Most of the countries analyzed have not yet reached the level of financial development considered as high. It is still room to apply policies to encourage the improvement of the financial system.

KEYWORDS: Bank credit; Economic growth; Financial development; Causality.
\end{abstract}

\section{RESUMO}

Objetivo: Este trabalho testa a hipótese de que o crédito bancário é necessário para o crescimento econômico, dependendo do nível de desenvolvimento econômico e financeiro do país. Busca-se também verificar se a relação entre desenvolvimento financeiro e crescimento econômico é monotônica. Método: Para isso, a metodologia de causalidade de Granger é utilizada para dados em painel referentes 106 países para o período entre 1970 e 2016 . Resultado: Observa-se que houve uma expansão do crédito mundial acima do crescimento econômico observado ao longo do período estudado. Os principais achados empíricos indicam que, de maneira generalizada, o crédito provoca crescimento econômico e vice-versa, além de verificar a não monotonicidade da relação entre desenvolvimento financeiro e crescimento econômico, sendo que para índices crédito/PIB muito baixos a causalidade do crédito para o PIB não é verificada. Conclusões: A maioria dos países analisados ainda não atingiu um nível de desenvolvimento financeiro considerado alto. Assim, ainda há espaço para a aplicação de políticas de incentivo à melhoria do sistema financeiro. PALAVRAS-CHAVE: Crédito bancário; Crescimento econômico; Desenvolvimento financeiro; Causalidade

Classificação JEL: E51; G01; 016; 047

Recebido em: 09-04-2020. Aceito em: 20-07-2020. 


\section{INTRODUÇÃO}

The association between financial development and economic growth remains one of the most contentious relationships in the economy. Rescuing a tradition that begins in Bagehot (1873), Hicks (1969), Schumpeter (1997), King and Levine (1993) have shown how financial development would be an essential element for long-term economic growth. From this work, several papers have been published, pointing out the positive relationship between financial development and economic expansion, such as those by De Gregorio and Guidotti (1995), Levine (1997), Rajan and Zingales (1998), Levine et al. (2000), Beck et al. (2008), among others. However, following the 2008 Financial Crisis, several studies, such as by Jordà et al. (2010), Schularick and Taylor (2012), Paula and Crocco (2013), and Aikman et al. (2014) show the credit growth as a precursor to financial crises and, through this channel, capable of adversely affecting the long-term economic growth. Faced with this disparity, studies began to emerge with the hypothesis that the relationship between financial development and economic growth would not be a monotonically positive relationship, which is, regardless of the level of financial development achieved by the economy, as pointed out by Cecchetti and Kharroubi (2012) and Samargandi et al. (2015).

In general, the credit variable in proportion to the Gross Domestic Product is used as a proxy to measure the degree of financial development and, through it, to estimate its importance for economic growth. The idea is that the provision of credit would be related to the presence of institutions specialized in financial intermediation, which would play a fundamental role in optimizing the allocation of resources in order both to raise the savings rate of the economy and to increase the efficiency of investment decisions.

Credit leads to higher GDP since a greater supply of resources would extend investments in fixed capital and new technologies, in addition to increasing productivity, due to the reduction in the borrowing costs. On the other hand, the lack of a direct relationship between these variables can be justified by the fact that an increase in productivity also increases output and profits, providing more own resources for companies to make their investments, not requiring loans. The logic is the same for families, who raise their incomes in periods of economic expansion.

Faced with this contradiction, the main objective of this paper is to test the hypothesis that bank credit is necessary for economic growth, depending on the level of financial and economic development of the country. As specific objectives, we seek to prove the assumption that the relationship between financial development and economic expansion is 
not monotonic, in addition to analyzing the causality in the opposite direction, from GDP to credit. For this purpose, it uses Granger's causality methodology for panel data, containing data from 106 countries from 1970 to 2016.

Besides this introduction, this study is structured in four more sections, in addition to the final considerations. A brief review of the literature is shown below, seeking to explain the relationship between bank credit and economic growth. The third section presents the data and the method used for the causality test. In the fourth section, a description of the variables is made. Finally, in the fifth section, we analyze the results found by the estimates.

\section{CREDIT AND GROWTH: BRIEF STYLIZED FACTS}

Economic growth depends on real variables such as physical capital, human capital, technology, as well as labor supply, which is already widely understood and proven in Economic Theory by the studies of Solow (1956), Romer (1986), and Lucas (1988). However, the importance of the financial side, as a complementary variable and determinant of this growth, is not yet consolidated in economic theory.

There is no convergence in the empirical literature about the importance of bank credit for economic growth. On the one hand, King and Levine (1993) find favorable evidence to this thesis, given that financial development would be strongly correlated with economic growth, that preceding this. In this sense, several pieces of evidence that supports this hypothesis are presented in the works of Goldsmith (1969), McKinnon (1973), Bernanke (1983), De Gregorio and Guidotti (1995), Levine (1997), Rajan and Zingales (1998), Beck, Levine, and Loayza (2000), Levine, Loayza and Beck (2000), Beck and Levine (2001), Beck et al. (2008), Madsen and Ang (2016), among others. In Brazil, few studies seek to verify and prove this hypothesis, being relevant to highlight the studies of Matos (2002), Marques Jr. and Porto Jr. (2004), Cavalcante, Crocco e Brito (2007), and Rocha and Nakane (2007), who found strong evidence that financial variables impact economic growth. More recently, Paula Rocha and Souza (2018) used the domain control technique to find evidence of a positive long-term relationship between bank credit and economic growth in Brazil, considering annual data for the period from 1960 to 2010.

On the other hand, there are studies whose results suggest that the financial system does not play a relevant role in economic development. Robinson (1952) states that financial development simply accompanies economic growth. In addition, according to Lucas (1988), the relation between the financial sector and economic growth is overestimated. Likewise, 
Demetriades and Hussein (1996), Rousseau and Wachtel (2011), and Arcand et al. (2012) go in the same direction.

For Beck, Levine, and Loayza (2000), the more developed a country's financial system, the better the resource allocation. Thus, a well-developed financial system facilitates the efficient allocation of household consumption and physical capital for more productive use in the business sector (MERTON, 1995). In this sense, Levine (2004) empirically analyzes the relationship between the functioning of the financial system and economic growth. The author finds evidence that more developed financial systems reduce the constraints of external financing that many companies face, indicating that financial development influences economic growth.

Calderón and Liu (2002) aimed to verify the direction of causality between financial development and economic growth. According to the authors, the causal relationship between the financial system and economic growth is bicausal, being that the predominant one is the precedence of financial development, in addition to generating greater economic expansion due to the greater accumulation of capital with higher productivity. A similar result was found by Goldsmith (1969), who also found a positive relationship between the analyzed variables, besides verifying a causal relation of the financial development to the economic growth.

The divergence in the economic literature on the relationship between the financial system and economic growth is persistent. This paper has as main proposal to test the hypothesis of causality between such variables.

\section{METHODOLOGY}

\subsection{Data}

To carry out this study, the series of data of GDP in dollars at constant prices for the year 2010 and the domestic credit to the private sector, covering the period from 1970 to $2016^{1}$, were used annually, comprising a total of 106 countries. $^{2}$ The series was drawn from the International Monetary Fund (IMF), International Financial Statistics (IFS), the World Bank, and the Organization for Economic Co-operation and Development (OECD).

\footnotetext{
1 Of the 106 countries, 35 are members of the OECD; the other countries are divided between medium and low development. Altogether, there are 29 from the African continent, 31 from the American, 19 from the Asian, 25 from the European and 2 from Oceania.

${ }^{2}$ For the definition of the analysis period, the availability of data was decisive, especially those related to the supply of credit in low and medium development countries. Most developed countries, that is, OECD countries, have presented such data since 1960. For low-income countries, there is little data available in the period before the 1970s.
} 
The second series consists of financial resources provided to the private sector by financial firms, such as loans, purchases of securities and trade receivables, and other accounts receivable, which establish a request for reimbursement. For some countries, these claims include credit for public companies. Financial corporations include monetary authorities and deposit banks, as well as other financial firms in which the data are available, including companies that do not accept transferable deposits but incur liabilities such as deposits and savings. Other financial companies work with leasing, insurance, foreign exchange, and pension funds.

It should be noted that the variables used for the estimates were taken in their natural logarithms. Thus, when the unit root tests are done for panel data, it is concluded that, in both cases, the series are stationary in level, and no change is necessary.

\subsection{Method}

To verify the causal relationship between bank credit and economic growth, we use the Granger (1969) causality test. We seek to find a statistically significant temporal precedence among the studied variables, in which the Granger causality test is used for data in panel, which is not as used as in the case of time series. The main advantage of using such causality in the panel data is the greater number of observations, and the gain of degrees of freedom, increasing the efficiency of the estimated parameters.

Thus, like what occurs in time-series studies, the presence of a unit root in the series used may lead to undesired results, such as spurious regression. Therefore, the first step is to verify the stationarity of the series. If the unit root presence is verified, it is necessary to take the series in their differences and perform the tests again.

In the economic literature, there are several unit roots tests for panel data, such as Levin, Lin, and Chu (2002), Harris and Tzavalis (1999), Breitung (2000), Breitung and Das (2005), Im, Pesaran, and Shin (2003) and Choi (2001), who have a null hypothesis that all individuals have a unit root against the alternative that at least one is stationary. In turn, the null hypothesis of the Lagrange multiplier test (LM) of Hadri (2000) considers that all individuals are stationary, and the alternative that at least one has a unit root.

The method used in the present study is the one developed by Abrigo and Love (2016), which is based on the work of Holtz-Eakin, Newey, and Rosen (1988), and can be presented as a PVAR (panel vector auto-regression) as follows:

$$
Y_{i t}=\alpha_{1}+\delta_{1 i}+\sum_{l=1}^{m} \beta_{1 l} Y_{i t-l}+\sum_{l=1}^{m} \gamma_{1 l} X_{i t-l}+\varepsilon_{i t}
$$




$$
X_{i t}=\alpha_{2}+\delta_{2 i}+\sum_{l=1}^{m} \beta_{2 l} Y_{i t-l}+\sum_{l=1}^{m} \gamma_{2 l} X_{i t-l}+\mu_{i t}
$$

where $Y_{i t}$ represents the natural logarithm of GDP of a country $i$ in year $t$; is the natural logarithm of the volume of credit operations to the private sector of a country $i$ in year $t ; \delta_{1 i}$ and $\delta_{2 i}$ are the fixed effects of each nation, invariant in time and; I expresses the number of lags considered for the estimation $(I=1, \ldots, m)$.

The hypothesis to be tested in the model consists of non-causality in the sense of Granger, which is verified from the Wald test, in which constraints are applied to the estimated parameters of the model. Thus, if it is possible to reject the null hypothesis for some $\gamma_{1 l}$ 's of (1) and it is not possible to reject the null hypothesis for any $\beta_{2 l}$ 's of (2), we suggest causality in the sense of unilateral Granger from $X$ to $Y$. Symmetrically, if it is not possible to reject the null hypothesis for any $\gamma_{1 l}$ 's of (1) and if it is possible to reject the null hypothesis for some $\beta_{2 l}$ 's of (2), we suggest causality in the sense that Granger is unilateral from $Y$ to $X$. Bidirectional causality occurs if, at the same time, it is possible to reject $H_{0}$ for some $\gamma_{1 l}$ 's of (1) and $\beta_{2 l}$ 's of (2). Finally, if it is not possible to reject $H_{0}$ for any $\gamma_{1 l}$ 's of (1) and $\beta_{2 l}$ 's of (2), we conclude that there is no Granger causality between $X$ and $Y$.

A relevant point to highlight is the number of lags to be considered in the estimates, which can generate specification bias, increase the variance of the estimated parameters, and less accurate results. Thus, in this work, several tests were considered to verify the best number of lags of the VAR model, among which the Akaike (AIC) and Schwartz (SIC). So, from one to three lags were considered in this study if the effect of bank credit on economic growth and vice versa is not immediate.

In this study, the results were calculated using the method that, according to the literature, is the most appropriate: The Generalized Method of Moments (GMM), and the validity of the instruments used in all the estimates was verified by Hansen (1982) test. The Sargan-Hansen test of over-identifying constraints should be performed routinely on any super-identified model estimated with instrumental variables. It is emphasized that if a strong rejection of the null hypothesis of the Sargan-Hansen test is found, the validity of the estimates must be strongly doubted, since the model is possibly poorly specified, a problem that may have been caused by autocorrelation in the residues, invalidating the instruments.

Thus, as in time series, after making the estimates, it is necessary to verify if all the roots of the polynomial are inside the unit circle because if one is outside, the model cannot 
be considered stable and neither be used for predictions, since a temporary shock on a given variable will imply an explosive shock, being inconsistent for analysis.

Finally, if the stability tests of the model are satisfied, it is possible to use the impulseresponse tool, which, like the time series, has the function of analyzing the individual behavior of a particular variable in the face of shocks in the model residues or innovations.

\section{DESCRIPTIVE ANALYSIS}

The descriptive statistics of the variables used for this study are presented in Table 1. The average GDP of the 106 countries during the period between 1970 and 2016 was approximately US\$ 362.74 billion, being that this value is well below the maximum value observed in the sample, which was over US\$16.86 trillion, corresponding to the United States GDP in 2016. In turn, Saint Vincent and the Grenadines had the lowest GDP in the period, of just over US\$160 million, a value that was verified in the year 1975. For Brazil, it is observed that during this period, in only eight years, there was a slowdown in economic growth, with the worst result in 1981, when GDP fell by $4.4 \%$ when compared to the previous year; for its part, in 1973 was the year of the greatest growth, slightly more than $14 \%$.

Regarding the volume of credit operations, the average value was approximately US\$ 393.46 billion, slightly higher than the average of the product. Here again, the country that presented the largest offer of banking credit was the United States of America, worth more than US\$ 32.5 trillion in 2016. At the other extreme, the Republic of Liberia was the one that presented the lower credit volume, from just over US\$3.74 million in the year 1988 .

Concerning the correlation of the variables of the proposed model, the results presented in Table 1 suggest that the volume of credit operations has positive effects on economic growth, being this correlation of approximately $96.12 \%$.

Table 1 - Descriptive statistics of variables, 106 countries, 1970-2016

\begin{tabular}{|c|c|c|}
\hline \multirow{2}{*}{ Statistics } & \multicolumn{2}{|c|}{ Variables } \\
\hline & GDP & Credit \\
\hline Average & US\$ 362.74 billion & US\$ 393.46 billion \\
\hline Median & US\$21.66 billion & US\$ 6.24 billion \\
\hline Maximum & US\$ $16,865.60$ billion & US\$ $32,506.52$ billion \\
\hline Minimum & US\$ 160,86 million & US\$ 3.74 million \\
\hline Default Error & US\$ $1,272.89$ billion & US\$ 2,052.11 billion \\
\hline Observations & 4,876 & 4,876 \\
\hline \multicolumn{3}{|c|}{ Correlation matrix } \\
\hline \multirow{2}{*}{ Variables } & \multicolumn{2}{|c|}{ Variables } \\
\hline & GDP & Credit \\
\hline GDP & 1 & \\
\hline
\end{tabular}


Figure 1 shows six data series, three of the average annual GDP of the countries and three of the average annual volume of credit operations of the countries, all for the period from 1970 to 2016 . In addition to the group of all 106 sample countries, to verify if there are large heterogeneity among the economies present in this study, they were divided among those that are members of the $\mathrm{OECD}^{3}$, considered here as developed ${ }^{4}$, and those who have not joined the Organization, which are considered as developing countries.

Initially, after analyzing the relations with the group with all the countries, it is verified that both series show an ascending trajectory, so that the average credit grows in a greater proportion, surpassing the average GDP in the mid-1990s. Thus, it is possible to divide the whole period into two subperiods: the first one, comprising from 1970 until the beginning of the 1990s, and the second, from the beginning of the 1990s until 2016.

At first, it is observed that the product is higher than the volume of credit, a situation that is reversed in the second subperiod, where the credit is higher than the GDP, thus indicating that, on average, countries began to leverage from such date, with a tendency for even greater expansion. The average volume of credit operations showed a usually positive trajectory, with only a few retraction points. Among them, it is possible to highlight the years 1974, 1975, 1977 and 2008, years in which world economic crises had, consequently, a restrictive credit policy.

Figure 1 - Average GDP and credit, in billions of US\$, 1970-2016

\footnotetext{
${ }^{3}$ In the present study, the 35 countries that were part of the Organization in the year 2016 were considered as members of the OECD.

${ }^{4}$ According to the World Bank, only Mexico and Turkey are said to be middle-income economies, and the other members are considered as high-income.
} 


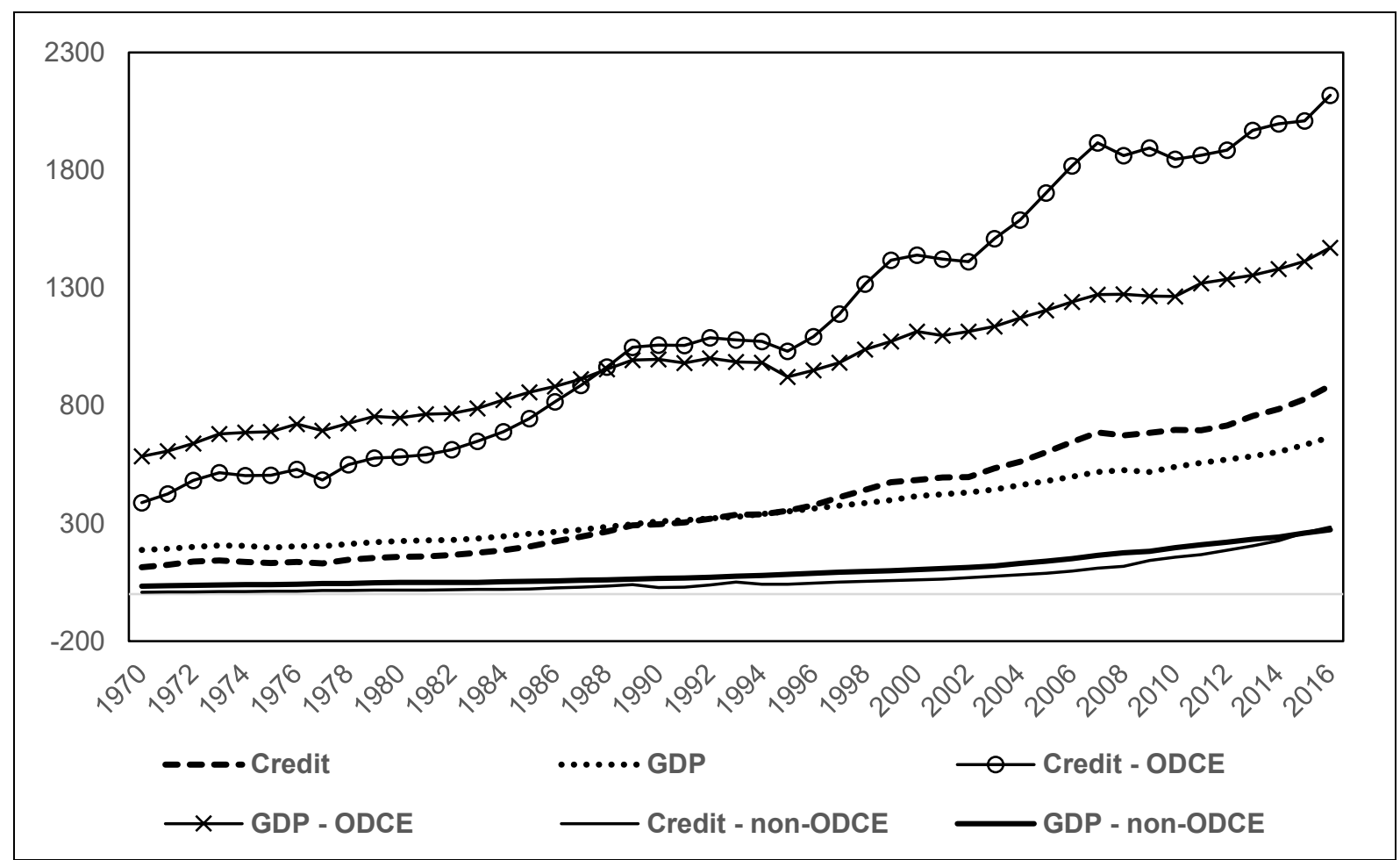

SOURCE: Research data. International Monetary Fund (IMF), International Financial

Statistics (IFS), the World Bank and Organization for Economic Co-operation and Development (OECD) database.

It is possible to make a similar analysis to the previous one when observing the curves' behavior referring to the member countries and non-members of OECD. However, in the case of the member countries, it is emphasized that the moment when the average volume of credit operations becomes higher than the average GDP occurs some years before that of the 106 countries, already in the late 1980s. In addition, throughout the analyzed period, the series values for this group of countries are higher than those for all countries.

In the case of countries that are not part of the Organization, in almost all historical series, the average GDP was higher than the average volume of credit operations, such position being reversed only in the year 2015. In addition, it is observed that both variables are at a lower level than observed by the previously analyzed groups.

Comparing the series of OECD member countries with non-OECD countries, it is suggested that, in developed countries, GDP and credit operations, on average, are higher than those in development, in addition to having an earlier financial development verified since the average credit-to-GDP ratio reaches $100 \%$ at an earlier point in time than the countries that are not members of the Organization. Iceland, one of the founding members of the OECD, was the country with the highest value in the credit-to-GDP ratio: 
approximately 3.12 in 2006, and the following year, this number decreased to 2.50 , above the average for the 106 countries in the analyzed period (approximately 0.42 ), as well as for OECD and non-OECD countries, which presented averages of 0.74 and 0.32 .

Thus, bank credit showed a trend of higher growth rates than GDP, thus suggesting the importance of the financial system in the world scenario for economic growth, which is in line with that proposed by Schumpeter (1997), considering that credit was the instrument of leverage that would result in economic growth.

\section{ANALYSIS OF RESULTS}

The first step to estimate the model proposed here is to verify the stationarity of the series used. Thus, Table 2 presents the results of the unit root tests used for the model considering the period from 1970 to 2016 with the 106 countries, being exposed the values calculated for GDP and bank credit level and both in natural logarithm, considering one, two and, three lags. The stationarity tests used here were those of Fisher, which have a null hypothesis that all the panels have a unit root.

Regardless of the test analyzed and the number of lags considered to estimate it, the results are similar, in that it is not possible to reject the hypothesis of unit root presence in all countries when testing the level series, thus suggesting that these are not stationary. Thus, when testing the series in their natural logarithms, the results are satisfactory, since for both the GDP variable and the credit variable it is possible to reject the null hypothesis at $1 \%$ of significance, regardless of the number of lags, indicating that, in this case, both series are stationary in level.

Once the stationarity of the series has been verified, the next step is to select the best number of lags to estimate the auto-regression vector panel model. As in the economic literature, there is no consensus as to the best test to determine the number of lags. It was chosen to estimate the Bayesian, Akaike and Hannan and, Quinn, and from these, it is concluded that the best number of lags to carry out the estimates is two. ${ }^{5}$

Table 2 - Fisher unit root tests for panel data

\begin{tabular}{cccccc}
\hline Lags & Variables & $\begin{array}{c}\text { Inverse chi- } \\
\text { squared (212) }\end{array}$ & $\begin{array}{c}\text { Inverse } \\
\text { normal }\end{array}$ & $\begin{array}{c}\text { Inverse logit } \\
\mathbf{t ( 5 3 4 )}\end{array}$ & $\begin{array}{c}\text { Modified inv, } \\
\text { chi-squared }\end{array}$ \\
\hline \multirow{2}{*}{1} & GDP & 81.7607 & 21.8757 & 26.8802 & -6.3250 \\
& Credit & 105.2025 & 14.2055 & 15.2633 & -5.1865
\end{tabular}

\footnotetext{
${ }^{5}$ In the other models estimated throughout this work, following the same criteria, the suggested number of lags diversify.
} 


\begin{tabular}{cccccc}
\hline & InGDP & $1039.4788^{* * *}$ & $-21.4857^{* * *}$ & $-26.8735^{* * *}$ & $40.1859^{* * *}$ \\
& Incred & $728.3259^{* * *}$ & $-17.3656^{* * *}$ & $-18.7539^{* * *}$ & $25.0750^{* * *}$ \\
\hline \multirow{3}{*}{2} & GDP & 75.7013 & 22.2981 & 27.5122 & -6.6192 \\
& Credit & 102.9498 & 12.8037 & 13.4544 & -5.2959 \\
& InGDP & $987.1761^{* * *}$ & $-21.0303^{* * *}$ & $-25.6315^{* * *}$ & $37.6459^{* * *}$ \\
& Incred & $746.3565^{* * *}$ & $-17.6736^{* * *}$ & $-19.2036^{* * *}$ & $25.9506^{* * *}$ \\
\hline & GDP & 80.1324 & 19.6850 & 23.1440 & -6.4041 \\
3 & Credit & 113.1618 & 11.9576 & 12.2855 & -4.8000 \\
& InGDP & $813.1917^{* * *}$ & $-17.6360^{* * *}$ & $-20.4062^{* * *}$ & $29.1964^{* * *}$ \\
& Incred & $733.1656^{* * *}$ & $-17.5478^{* * *}$ & $-18.9472^{* * *}$ & $25.3100^{* * *}$ \\
\hline
\end{tabular}

SOURCE: Research data. International Monetary Fund (IMF), International Financial Statistics (IFS), the World Bank and Organization for Economic Co-operation and Development (OECD) database. Note: ${ }^{* * *}$ Level of significance of $1 \%$; ${ }^{* *}$ Level of significance of $5 \%$; ${ }^{*}$ Significance level of $10 \%$

However, to verify if the bank credit variable can help predict economic growth, and vice versa, regardless of an exact number of lags and the specific model that is generating such a forecast, we also estimated the models considering one and three lags, to compare the results obtained and to test which model fits better. Thus, an arbitrary but flexible criterion was used, as done by Rocha and Nakane (2007) and Hurlin and Venet (2008).

Table 3 presents Granger's causality tests between economic growth and financial development considering all the 106 analyzed countries, for the entire period from 1970 to 2016. From the presented results, it is possible to infer that bank credit causes economic growth in the sense of Granger, regardless of the number of lags considered in the estimate since in the three estimates presented it was possible to reject the null hypothesis at $5 \%$ significance. In other words, up to three lags, the evidence suggests that credit causes economic growth in the sense of Granger. ${ }^{6}$

Table 3 - Granger causality test, between economic growth and bank credit, 106 countries, 1970-

\begin{tabular}{ccccccr}
\hline Lags & \multicolumn{9}{c}{$\begin{array}{c}\text { Credit does not } \\
\text { Granger cause } \\
\text { economic growth }\end{array}$} & \multicolumn{2}{c}{$\begin{array}{c}\text { Economic growth does } \\
\text { not Granger cause } \\
\text { credit }\end{array}$} & \multicolumn{2}{c}{$\begin{array}{c}\text { Hansen's } \\
\text { Statistics J }\end{array}$} \\
\hline & Wald & Prob. & Wald & Prob & J & Prob \\
\hline 1 & 13.084 & 0.000 & 4.027 & 0.045 & 11.18 & 0.19 \\
2 & 13.045 & 0.001 & 8.127 & 0.017 & 3.97 & 0.41
\end{tabular}

\footnotetext{
${ }^{6}$ These results were also estimated considering credit per capita and GDP per capita, seeking to test the robustness of the estimates. As an example, the correlation between the two series is equal to 0.8243 , both series were stationary in natural logarithm, it was possible to reject the null hypothesis at $5 \%$ significance, for both lags, concerning non-Granger credit causes growth economic [11,931 $(0,003)]$, economic growth does not cause credit to Granger $[11,319(0,003)]$ and Hansen's statistics indicate that the instruments were valid. Thus, the results were maintained.
} 


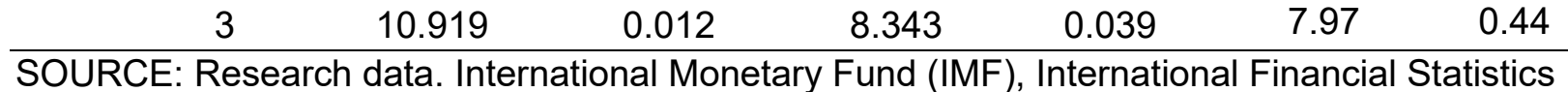
(IFS), the World Bank and Organization for Economic Co-operation and Development (OECD) database.

An analogous result is obtained when evaluating whether the economic growth Granger-cause credit. It is observed that, for the different numbers of lags considered in the estimates, it is possible to reject $H_{0}$ at the $5 \%$ level of significance, if growth causes financial development in the sense of Granger, thus having a bidirectional causality between the variables.

As already explained in the previous section, the Hansen test was used to verify if the instruments used in the estimations were valid. Thus, analyzing the tests for the three levels of lags, the validity of the instruments is verified, since it was not possible to reject the null hypothesis of good specification of the proposed models in none of the cases. ${ }^{7}$

The results so far presented, although consistent with the economic literature, are generic, since they do not consider the temporal evolution of the financial systems, as well as the inherent differences in the countries under study, since the set of economies in the analysis is quite heterogeneous, as shown in Figure 1. Thus, the next two sections seek to establish such distinctions to verify the causal relationship between bank credit and economic growth, initially segmenting the studied period and, later, disaggregating the countries analyzed in developed and developing countries.

\subsection{The relationship between credit and economic growth from 1970 to 1989 and from 1990 to 2016}

Throughout the last three decades of the twentieth century, national economies began to adopt a position of greater financial liberalization, allowing greater inflow and outflow of capital at their respective frontiers. In developed countries, this process of integration began in the early 1970s with the end of the Bretton Woods Agreement, gaining strength in the following two decades. In the case of developing countries, this openness has taken place in the late 1980s, intensifying in the 1990s (DAMASCENO, 2007).

Moreover, when analyzing Figure 1, it is possible to verify that, considering all the 106 countries taken in this study, the volume of average credit operations exceeds the average GDP at the beginning of the 1990s, a fact that occurs at the end of the decade

7 This conclusion can be made for all models presented throughout the work. 
before taking only the OECD member countries. This is related to the process of financial liberalization that began to be observed in the 1970s (VASCONCELOS et al. 2003). Thus, to verify if there were significant changes in the causality between financial development and economic growth during the financial liberation process, the analysis was segmented into two subperiods, the first one from 1970 until 1989 and the second from 1990 until 2016.

The results of the first subperiod are presented in the first part of Table 4 , and for comparison, besides considering all the economies analyzed, two complementary models were estimated to eliminate possible countries that could be distorting the results, that is, countries with a high level of financial development, whose credit-to-GDP ratio was greater than $90 \%$.

After examining the obtained results, it can be observed that, in all the estimates, it is possible to reject the null hypothesis that financial development does not cause economic growth in the sense of Granger, regardless of the number of lags considered. Moreover, when comparing the complementary models, it is verified that as the countries with high financial development indices are eliminated, the significance of the parameters improves, giving indications that, possibly, in these economies, this causal relationship may not be present, distorting the estimates.

Regarding the causality of GDP for credit, in all models, it was also possible to conclude by causality, regardless of the number of lags adopted for the estimates. Thus, it can be inferred that, in the period between 1970 and 1989, in which financial liberalization had not yet reached the national economies in general, the causality between financial development and economic growth was bidirectional.

For the second period, it can be noted that financial liberalization reaches countries more universally, so that the level of average financial development, measured here by the average credit-GDP ratio of economies, which in the previous period was $30 \%$, happened to be approximately $50 \%$. Thus, the second part of Table 4 presents the Granger causality tests for the period from 1990 to 2016, and here, in addition to the estimates considering all countries in the sample, four complementary models are presented for comparison.

The first three models are the same as those presented for the years 1970 to 1989. The analyses are also remarkably similar so that Granger's causation in financial development for economic growth is confirmed in all estimates, regardless of the number of lags considered. The same goes for testing causality in the opposite direction, except for the estimate excluding the countries that reached the level of financial development here considered as high, of $90 \%$, considering a single lag. 
The last two models of the second subperiod are additional to those of the first. Considering only the countries that have reached the $90 \%$ credit-to-GDP ratio to carry out the estimates, the results regarding the causality of financial development for economic growth are like the previous ones, that is, it is possible to reject $H_{0}$. In turn, when testing causality in the opposite direction, the results obtained are opposite. It is not possible to conclude that Granger-cause bank credit and GDP growth, given that for any level of lag taken, it does not reject $H_{0}$. This finding may be justified by the fact that countries that have reached a high credit-to-GDP ratio, more than 90\%, already have a high level of financial development, so that greater economic growth does not generate significant impacts on the evolution of the financial system.

When testing the causality in those countries that showed an earlier financial development, such as those that had a credit-to-GDP ratio of over $90 \%$ already in 1990 , a relationship that remained until the year 2016, interesting results were obtained. ${ }^{8}$

Table 4 - Granger causality test between economic growth and bank credit, 1970-1989 and

\begin{tabular}{|c|c|c|c|c|c|c|}
\hline \multirow[t]{2}{*}{ Lags } & \multicolumn{2}{|c|}{$\begin{array}{l}\text { Credit does not } \\
\text { Granger cause } \\
\text { economic growth }\end{array}$} & \multicolumn{2}{|c|}{$\begin{array}{c}\text { Economic growth } \\
\text { does not Granger } \\
\text { cause credit }\end{array}$} & \multicolumn{2}{|c|}{$\begin{array}{l}\text { Hansen's } \\
\text { Statistics J }\end{array}$} \\
\hline & Wald & Prob. & Wald & Prob & $\mathbf{J}$ & Prob \\
\hline \multicolumn{7}{|c|}{$1970-1989$} \\
\hline \multicolumn{7}{|c|}{ All 106 countries } \\
\hline 1 & 8.286 & 0.004 & 3.778 & 0.052 & 1.65 & 0.80 \\
\hline 2 & 4.881 & 0.087 & 7.562 & 0.023 & 12.77 & 0.39 \\
\hline 3 & 6.987 & 0.072 & 7.720 & 0.052 & 11.58 & 0.77 \\
\hline \multicolumn{7}{|c|}{ Excluding countries with a credit-to-GDP ratio greater than $90 \%$ in all periods } \\
\hline 1 & 8.102 & 0.004 & 3.246 & 0.072 & 1.54 & 0.82 \\
\hline 2 & 6.251 & 0.044 & 9.277 & 0.010 & 11.57 & 0.77 \\
\hline 3 & 7.659 & 0.054 & 8.299 & 0.040 & 49.75 & 0.26 \\
\hline \multicolumn{7}{|c|}{ Excluding countries that achieved a credit-to-GDP ratio of $90 \%$} \\
\hline 1 & 10.446 & 0.001 & 3.086 & 0.079 & 31.57 & 0.29 \\
\hline 2 & 6.603 & 0.037 & 9.397 & 0.009 & 64.64 & 0.11 \\
\hline 3 & 8.960 & 0.030 & 7.233 & 0.065 & 35.78 & 0.48 \\
\hline \multicolumn{7}{|c|}{$1990-2016$} \\
\hline \multicolumn{7}{|c|}{ All 106 countries } \\
\hline 1 & 4.529 & 0.033 & 6.221 & 0.013 & 7.94 & 0.09 \\
\hline 2 & 5.211 & 0.074 & 44.800 & 0.000 & 66.62 & 0.08 \\
\hline
\end{tabular}

\footnotetext{
8 To make clear the difference between the economies considered in this model and those of the previous one, it should be noted that the average credit-GDP ratio of that group of countries was $100 \%$, compared to more than $164 \%$ of this one.
} 


\begin{tabular}{ccccccc}
3 & 8.419 & 0.038 & 39.092 & 0.000 & 59.70 & 0.22 \\
\hline \multicolumn{7}{c}{ Excluding countries with a credit-to-GDP ratio } \\
\hline 1 & 3.771 & 0.052 & 4.869 & 0.027 & 7.73 & 0.10 \\
2 & 5.341 & 0.069 & 49.859 & 0.000 & 65.62 & 0.18 \\
3 & 8.698 & 0.034 & 42.598 & 0.000 & 54.43 & 0.38 \\
\hline 1 & Excluding countries that achieved a credit-to-GDP ratio of $90 \%$ \\
2 & 5.012 & 0.025 & 1.210 & 0.271 & 5.69 & 0.22 \\
3 & 4.937 & 0.085 & 79.436 & 0.000 & 63.59 & 0.35 \\
\hline \multicolumn{7}{c}{ Estimating only with countries that reached the credit-GDP ratio of $90 \%$} \\
\hline 1 & 18.579 & 0.000 & 0.174 & 0.677 & 12.92 & 0.11 \\
3 & 8.336 & 0.015 & 2.612 & 0.271 & 1.99 & 0.74 \\
3 & 6.466 & 0.091 & 5.341 & 0.148 & 30.92 & 0.52 \\
\hline
\end{tabular}

SOURCE: Research data. International Monetary Fund (IMF), International Financial Statistics (IFS), the World Bank and Organization for Economic Co-operation and Development (OECD) database

Thus, considering this result in conjunction with those previously presented, it is possible to suggest the presence of evidence that the causal relationship between bank credit and economic growth is not monotonic for two main reasons. First, by excluding credit-GDP economies greater than $90 \%$, the causal relationships are more significant. Second, in making estimates only with countries that presented a level of financial development greater than this level throughout the period 1990-2016, there was no causality of credit for GDP.

\subsection{Economic and financial development and the relationship between credit and economic growth}

Considering the economic development, institutional framework, and financial system of the 106 countries as equals may not be the best way to analyze the relationship between bank credit and economic growth. Different economies have the most unequal institutional levels, as well as different levels of economic and financial development.

As shown in Figure 1, it is possible to verify an inequality between the GDP average and the bank credit for the OECD member and non-OECD member countries, considered as developed and developing, respectively. Thus, to analyze whether there are differences in causality in this study when considering countries with different levels of economic 
development, individual estimates were made for the two groups of countries, with the results presented in Table 5.

For OECD members, both in the full period and in the two subperiods, it is possible to conclude from the Granger causality of credit for growth, since in all the estimates it was possible to reject the null hypothesis. An important note should be made here. When comparing the results of the first subperiod with those of the second, it is observed that, over the years, the significance of the estimated coefficients decreases, although they remain significant. This finding gives evidence that, from a given level of financial development, the causal relationship that has been verified tends to disappear, since the average credit-toGDP ratio went from $52 \%$ to approximately $87 \%$ between subperiods.

By focusing on causality in the reverse direction, the estimates are inconclusive when considering the period from 1970 to 2016. However, the segmentation process concludes with Granger's causality in the direction of GDP for credit at the first moment, a result that disappears with the temporal evolution, ${ }^{9}$ which can be explained by the fact that OECD members, in the period 1990-2016, already have high levels of financial development, so that greater economic growth has little or no effect on that.

Table 5 - Granger causality test between economic growth and bank credit, OECD member and non-member countries, 1970-2016

\begin{tabular}{|c|c|c|c|c|c|c|}
\hline \multirow[t]{2}{*}{ Lags } & \multicolumn{2}{|c|}{$\begin{array}{r}\text { Credit does } \\
\text { not Granger cause } \\
\text { economic growth }\end{array}$} & \multirow{2}{*}{$\begin{array}{c}\text { Economic } \\
\text { does not } \\
\text { cause credit } \\
\text { Wald }\end{array}$} & \multirow{2}{*}{$\begin{array}{l}\begin{array}{c}\text { growth } \\
\text { Granger }\end{array} \\
\text { Prob } \\
\end{array}$} & \multicolumn{2}{|c|}{ Hansen's Statistics J } \\
\hline & Wald & Prob. & & & $\mathbf{J}$ & Prob \\
\hline \multicolumn{7}{|c|}{ OECD member countries } \\
\hline \multicolumn{7}{|c|}{$1970-2016$} \\
\hline 1 & 4.247 & 0.039 & 1.742 & 0.187 & 4.32 & 0.36 \\
\hline 2 & 13.797 & 0.001 & 7.180 & 0.028 & 12.27 & 0.14 \\
\hline 3 & 9.233 & 0.026 & 4.624 & 0.202 & 18.38 & 0.10 \\
\hline \multicolumn{7}{|c|}{$1970-1989$} \\
\hline 1 & 7.436 & 0.006 & 9.648 & 0.002 & 4.98 & 0.76 \\
\hline 2 & 95.319 & 0.000 & 8.639 & 0.013 & 22.02 & 0.14 \\
\hline 3 & 15.355 & 0.002 & 38.712 & 0.000 & 51.93 & 0.48 \\
\hline \multicolumn{7}{|c|}{$1990-2016$} \\
\hline 1 & 3.450 & 0.063 & 1.841 & 0.175 & 1.88 & 0.76 \\
\hline 2 & 5.733 & 0.057 & 0.574 & 0.750 & 26.00 & 0.57 \\
\hline 3 & 10.207 & 0.017 & 2.381 & 0.497 & 17.84 & 0.93 \\
\hline
\end{tabular}

${ }^{9}$ Consistent with those presented in the previous section when estimating only those countries that presented a high level of financial development. 


\begin{tabular}{ccccccc}
\hline \multicolumn{7}{c}{ Non-OECD countries } \\
\hline \multicolumn{7}{c}{$1970-2016$} \\
\hline 1 & 0.354 & 0.552 & 3.128 & 0.077 & 0.103 & 0.37 \\
3 & 1.513 & 0.469 & 8.086 & 0.018 & 4.61 & 0.97 \\
\hline 1 & 5.522 & 0.137 & 18.887 & 0.000 & 7.20 & 0.51 \\
\hline 2 & 2.610 & 0.106 & 5.740 & 0.017 & 28.89 & 0.22 \\
3 & 2.682 & 0.262 & 5.058 & 0.080 & 5.52 & 0.24 \\
\hline 1 & 1.970 & 0.579 & 3.143 & 0.370 & 2.70 & 0.61 \\
\hline 2 & 7.611 & 0.006 & 12.019 & 0.001 & 20.35 & 0.20 \\
3 & 6.158 & 0.046 & 42.660 & 0.000 & 47.29 & 0.50 \\
\hline
\end{tabular}

SOURCE: Research data. International Monetary Fund (IMF), International Financial Statistics (IFS), the World Bank and Organization for Economic Co-operation and Development (OECD) database

In non-OECD countries, it can be seen that in the whole period, for all estimates, causality is one-way from economic growth to financial development. However, in analyzing such a group of countries in terms of evolution over the years, the analysis differs.

It is possible to verify that in the first moment, when these economies were showing low financial development, an average of less than $25 \%$ in the period $1970-1989$, this is not concluded by the causality of the credit for the GDP, being not conclusive the causality in the opposite direction. However, since 1990, with the financial development that also occurred in this group of countries, with an average of more than $36 \%$ of the credit-to-GDP ratio for the second period, there is a bidirectional causality.

The analyses made for the groups of OECD and non-OECD member countries corroborate with the idea presented above of the causal relationship between bank credit and economic growth, not to be monotonic for two more reasons: iii) from a certain high level of financial development the significance of the causality parameters of credit to GDP decreased and iv) up to a certain low level of financial development, there was no causality of credit to GDP.

Seeking to verify if the causal relationship between financial development and economic growth is monotonic, the 106 sample countries were divided into three levels in terms of their respective average financial development. Economies with lower levels were allocated in the first group, referring to those with values lower than $25 \%$ regarding the creditto-GDP ratio. Already those with higher levels were inserted at the level of a ratio greater 
than $70 \%$, and the others were in the middle level of financial development, comprising from $25 \%$ to $70 \%$.

Table 6 shows the results of the estimates considering these three levels of countries. For economies with low levels of financial development, it is possible to verify that credit does not Granger cause GDP since for any number of lags adopted it is not possible to reject $H_{0}$, a result that corroborates that for low levels of financial development, there is no credit causality for economic growth.

This result changes for the group of countries with an average credit-to-GDP ratio of between $25 \%$ and $70 \%$, since for this it concludes with Granger's causality in financial development for GDP, for all lags adopted, confirming the results presented that in economies with a developed financial system, bank credit can influence economic growth.

However, when considering countries with remarkably high financial development, represented by the group with an average ratio higher than $70 \%$, estimates show that bank credit does not cause GDP growth, supporting the hypothesis that to remarkably high levels of financial development, such variable has no significant effect on economic growth.

Thus, these results suggest that the assumption of the relationship between financial development and growth is not monotonic so that until a certain low level of credit-GDP ratio, the financial system does not have a significant impact on the economy, becoming significant in countries with considerable levels of financial development. However, from a certain high level of system development, this relationship again stops existing.

Table 6 - Granger causality test, between economic growth and bank credit, average of the period, 1970-2016

\begin{tabular}{ccccccc}
\hline Lags & \multicolumn{2}{c}{$\begin{array}{c}\text { Credit does not } \\
\text { Granger cause } \\
\text { economic growth }\end{array}$} & \multicolumn{2}{c}{$\begin{array}{c}\text { Economic growth } \\
\text { does not Granger } \\
\text { cause credit }\end{array}$} & \multicolumn{2}{c}{$\begin{array}{c}\text { Hansen's } \\
\text { Statistics J }\end{array}$} \\
\cline { 2 - 7 } & Wald & Prob. & Wald & Prob & J & Prob \\
\hline \multicolumn{7}{c}{ Average credit-to-GDP ratio < 25\% } \\
\hline 1 & 2.289 & 0.130 & 2.957 & 0.086 & 29.23 & 0.21 \\
2 & 1.247 & 0.536 & 9.924 & 0.007 & 42.73 & 0.35 \\
3 & 6.060 & 0.109 & 9.281 & 0.026 & 14.72 & 0.26 \\
\hline 1 & 4.421 & 0.035 & 2.832 & 0.092 & 4.50 & 0.34 \\
2 & 5.715 & 0.057 & 5.490 & 0.064 & 57.08 & 0.58 \\
3 & 8.100 & 0.044 & 12.774 & 0.005 & 100.77 & 0.68 \\
\hline \multicolumn{7}{c}{ Average credit-to-GDP ratio $>25 \%$ and $<70$} \\
\hline 2 & Average credit-to-GDP ratio $>70 \%$ & & \\
\hline 3 & 0.023 & 0.879 & 0.814 & 0.367 & 10.48 & 0.23 \\
\hline
\end{tabular}


SOURCE: Research data. International Monetary Fund (IMF), International Financial

Statistics (IFS), the World Bank and Organization for Economic Co-operation and

Development (OECD) database

In turn, when testing the causality in the opposite direction, from GDP to bank credit, the presented results go in the same direction as those presented in previous estimates. That is, economic growth causes financial development up to a certain level, ceasing to be determinant in high levels of the credit-GDP ratio since in these cases the financial system has already reached a high degree of development.

Although there is no consensus about the relationship between the financial system and economic growth, several studies point to the existence of a causal relationship between such variables. The results presented here are in line with most of the empirical literature, which, when analyzing variables related to the financial system, found a positive relation with economic growth, highlighting Goldsmith (1969), McKinnon (1973), Bernanke (1983), King and Levine (1993), Beck, Levine and Loayza (2000), Levine, Loayza and Beck (2000), Beck and Levine (2001), Cecchetti et al. (2005), Cecchetti and Kharroubi (2012), Madsen and Ang (2016), Matos (2002), Marques Jr. and Porto Jr. (2004), Rocha and Nakane (2007) and Paula Rocha e Souza (2018).

It should be noted that the results of the present study identify one of the factors for the non-convergence of the evidence in the literature, that is, that the validity of the causality hypothesis between credit and economic growth is more robust only for countries with intermediate development of their financial system.

\section{FINAL CONSIDERATIONS}

The focus of this study was to verify the relationship between bank credit and economic growth, aiming to test if there is a causal relationship between such variables. More precisely, if there is temporal precedence between financial development and economic expansion, using Granger's causation method. For this purpose, annual data on credit operations to the domestic private sector and GDP were used for 106 countries, between 1970 and 2016.

There is a correlation of approximately $96 \%$ between GDP and credit, suggesting that there is a positive relationship between the variables. In this way, several estimates were made, considering from one to three lags, since the main objective of this work was to analyze if the bank credit variable was able to help predict economic growth, and contrariwise. 
Analyzing the test results, it was possible to infer that Granger's causality between financial development, measured here as the credit-GDP ratio, and economic growth is bidirectional. That is, bank credit causes economic expansion and vice versa, a result consistent with much of the literature.

However, the countries analyzed here are very heterogeneous, and there has been a trend of generalized financial liberalization over the period studied. Thus, to capture such differences, the estimates were made by segmenting the countries into groups and by period.

Thus, the results obtained with all 106 countries show that, for the period before and after financial liberalization, the causality between credit and GDP is bidirectional. However, in estimating only those countries that had a well-developed financial system as early as the 1990s, causality ceases to exist in both directions. In addition, for those who have achieved such financial development, causality only comes from credit for economic growth.

Moreover, in countries considered as developed, there is a causality of the financial system for economic growth over the years. However, causality in the opposite direction is only confirmed in the previous period to the one in which financial liberalization occurred globally. On the other hand, in developing economies the causality of the credit for the GDP only happens to occur from the decade of 1990.

Finally, the results suggest the non-monotonicity of the relationship between financial development and economic growth. Thus, in economies with a low or high credit-to-GDP ratio, credit is not capable of generating economic expansion. Still, in countries with a very advanced financial system, greater economic growth is incapable of stimulating an even greater development of this system.

Despite this conclusion, it is important to note that most of the countries analyzed have not yet reached the level of financial development considered as high. Thus, in general, it is possible to conclude that there is still room to apply policies within the financial system to encourage the improvement of the system, increasing the volume of credit operations, resulting in a stimulus to economic growth.

Economic growth has been discussed and studied for some time in the economic literature. Physical capital, human capital, technology, and labor supply are considered real factors that allow growth to occur. However, the importance of the financial side in this process is increasingly evident, with credit being a determinant of economic growth. 


\section{REFERENCES}

ABRIGO, M. R. M.; LOVE, I. Estimation of panel vector autoregression in Stata. Stata Journal. v.16, n.3, p. 778-804, 2016

AIKMAN, D.; HALDANE, A. G.; NELSON, B.D. Curbing the credit cycle. Economic Journal, v.125, n. 585, p. 1072-1109, 2014.

ARCAND, J. L.; BERKES, E; PANIZZA, U. Too Much Finance? IMF Working Paper n. 12/161. 2012.

BAGEHOT, Walter. Lombard street. Homewood, IL: Richard D. Irwin. (1962 Edition). 1873.

BECK, T.; LEVINE, R. Stock markets, banks and growth: Correlation or causality? The World Bank. Policy Research Working Paper Series, n. 2670, 2001.

BECK, T.; LEVINE, R.; LOAYZA, N. Finance and sources of growth. Journal of Financial Economics. v. 58. p. 261-300, 2000.

BECK, T.; DEMIRGUC-KUNT, A.; LAEVEN, L.; LEVINE, R. Finance, Firm Size, and Growth. Journal of Money, Credit and Banking, v.40, n. 7, p. 1379-1405, 2008.

BERNANKE, B. Non-monetary effects of financial crisis in propagation of Great Depression. American Economic Review. v. 73. p. 257-276, 1983.

BREITUNG, Jörg. The local power of some unit root tests for panel data. In: Nonstationary panels, panel cointegration, and dynamic panels. Emerald Group Publishing Limited, p. 161-177, 2001.

BREITUNG, J.; DAS, S. Panel unit root tests under cross-sectional dependence. Statistica Neerlandica, v. 59, p. 414-433, 2005.

CALDERÓN, C; LIU, L. The direction of causality between financial development and economic growth. Central Bank of Chile. Working Paper, n. 184, 2002.

CAVALCANTE, A. T. M.; CROCCO, M.; BRITO, M. L. A. Impactos macroeconômicos na variação regional da oferta de crédito. Análise Econômica, ano 25, n. 47, p. 85-120, 2007.

CECCHETTI, S. G.; KHARROUBI, E. Reassessing the impact of finance on growth. BIS Working Papers, n. 381, jul, 2012.

CECCHETTI, S; MOHANTY, M.; ZAMPOLLI, F. The real effect of debt. BIS Working Papers, n 352, 2011.

$\mathrm{CHOI}, \mathrm{I}$. Unit root tests for panel data. Journal of International Money and Finance. v.20, p. 249-272, 2001.

DAMASCENO, A. O. Integração financeira internacional e crescimento econômico: uma crítica a abordagem convencional. Economia e Sociedade, v. 16, n. 2, p. 171-98, 2007.

DE GREGORIO, J.; GUIDOTTI, P. E. Financial development and economic growth. World Development, v. 23, n. 3, p. 433-448, 1995. 
DEMETRIADES, P.; HUSSEIN, K. Does financial development cause economic growth? Time-series evidence from 16 countries. Journal of Development Economics, v. 51, p. 387-411. 1996.

GOLDSMITH, R. W. Financial Structure and Development. New Haven, CT: Yale University Press, 1969.

GRANGER, C. Investigating causal relations by econometric models and cross spectral methods. Econometrica, v. 37, p. 424-438, 1969.

HADRI, K. Testing for stationarity in heterogeneous panel data. Econometrics Journal, $\mathrm{n}$. 3, p. 148-161, 2000.

HANSEN, L. P. Large sample properties of generalized method of moments estimators. Econometrica, p. 1029-1054, 1982.

HARRIS, R. D.F.; TZAVALIS, E. Inference for unit roots in dynamic panels where the time dimension is fixed. Journal of Econometrics, v. 91, n. 2, p. 201-226, 1999.

HICKS, John. A theory of economic history. Oxford: Clarendon Press, 1969.

HOLTZ-EAKIN, D.; NEWEY, W.; ROSEN, H. S. Estimating Vector Autoregressions with panel data. Econometrica. v. 56, p. 1371-1395. 1988.

HURLIN, C.; VENET, B. Financial Development and Growth: A Re-Examination using a Panel Granger Causality Test. Working Papers N. halshs-00319995_v1, Hyper Article en Ligne, Sciences de l'Homme et de la Société, 2008.

IM, K. S.; PESARAN, M. H.; SHIN, Y. Testing for unit roots in heterogeneous panels. Journal of Econometrics, v. 115, p. 53-74. 2003.

JORDÀ, Ò.; SCHULARICK, M.; TAYLOR, A.M. Financial crises, credit booms, and external imbalances: 140 years of lessons. IMF Economic Review, v. 59, n.2, p. 340-378, 2010.

KING, R. G.; LEVINE, R. Finance and growth: Schumpeter might be right. The Quarterly Journal of Economics, v. 108, n. 3, p. 717-737, 1993.

LEVIN, A.; LIN, C. F.; CHU, C. S. J. Unit root tests in panel data: Asymptotic and finitesample properties. Journal of Econometrics, v. 108, p. 1-24. 2002.

LEVINE, R. Finance and growth: Theory and evidence. National Bureau of Economic Research - NBER. NBER Working Paper, n. 10766. 2004.

LEVINE, R. Financial Development and Economic Growth: Views and Agenda. Journal of Economic Literature, v. 35, p. 688-726, 1997.

LEVINE, R.; LOAYZA, N.; BECK, T. Financial intermediation and growth: Causality and causes. Journal of Monetary Economics, v. 46, p. 31-77. 2000.

LUCAS, R. E. Jr. On the mechanism of economic development. Journal of Monetary Economics, v. 22., p. 3-42. 1998. 
MADSEN, J.; ANG, J. Finance-led growth in the OCDE since the nineteenth century: How does financial development transmit to growth? Review of Economics and Statistics, v. 98, n. 3, p. 552-572, 2016.

MARQUES JR., T. E.; PORTO JR., S. S. Desenvolvimento financeiro e crescimento econômico no Brasil - Uma avaliação econométrica. PPGE/UFRGS. Trabalho para Discussão n. 11. 2004.

MATOS, O. C. Desenvolvimento do sistema financeiro e crescimento econômico no Brasil: Evidência de causalidade. Banco Central do Brasil. Trabalho para Discussão, n. 49. 2002.

MCKINNON, Ronald lan. Money and Capital in Economic Development. Washington, DC: Brookings Institution, 1973.

MERTON, R. C. A functional perspective of financial intermediation. Financial Management, v. 24, n. 2, p. 23-41, 1995.

MISSIO, F.; JAYME JR., F.; OLIVEIRA, A. M. Desenvolvimento financeiro e crescimento econômico: teoria e evidência empírica para os estados brasileiros (1995-2004). Texto para Discussão CEDEPLAR/UFMG., n. 379, p. 1-34, 2010.

PAULA, T. H. P.; CROCCO, M. Financiamento e diversidade produtiva: um modelo baseado em agentes com flutuações cíclicas. Revista de Economia Contemporânea, v. 17, n. 1, p. 5-38, 2013.

RAJAN, R. G.; ZINGALES, L. Financial dependence and growth. The American Economic Review, v. 88, p. 559-586, 1998.

REGINATO, V. G.; CUNHA, M. S.; VASCONCELOS, M. R. Crédito rural e nível de atividade da agropecuária brasileira: uma análise de causalidade em painel. Revista de Economia e Agronegócio, v. 17, nº 3, p. 442-461, 2019.

ROBINSON, J. The Generalization of the General Theory. In: The Rate of Interest and Other Essays, London: MacMillan, 1952.

ROMER, David. Advanced macroeconomics, 5 ed. Dubuque: McGraw-Hill, 2019.

ROMER, P. Increasing returns and long-run growth. Journal of Political Economy. v. 94, p. 1002-1037, 1986.

ROUSSEAU, P.; WACHTEL, P. What is Happening to The Impact of Financial Deepening on Economic Growth? Economic Inquiry, v. 49, p. 276-288, 2011.

SAMARGANDI, N.; FIDRMUC, J.; GHOSHA, S. Is the Relationship Between Financial Development and Economic Growth Monotonic? Evidence from a Sample of Middle-Income Countries. World Development, v. 68, p. 66-81, 2015.

SCHULARICK, M.; TAYLOR, A.M. Credit booms gone bust: monetary policy, leverage cycles, and financial crises, 1870-2008. The American Economic Review, v. 102, n.2, p. 1029-1061, 2012. 
SCHUMPETER, Joseph Alois. A Teoria do Desenvolvimento Económico: uma investigação sobre lucros, capital, crédito, juro e o ciclo económico. Coleção Os Economistas. São Paulo: Ed. Abril, 1997.

SOLOW, R. "A contribution to the theory of economic growth". Quarterly Journal of Economics, v. 70, p. 65-74, 1956.

VASCONCELOS, M. R.; STRACHMAN, E.; FUCIDJI, J.R. Liberalização e desregulamentação bancária: motivações, consequências e adaptações. Nova Economia, v.13, n.1, p. 101-140, 2003. 